\title{
The status of Listera cordata cenopopulation in the nurgush state nature reserve
}

\author{
Sergey Bakka ${ }^{1}$ and Nadezhda Kiseleva ${ }^{2}$ \\ ${ }^{1}$ State Nature Reserve "Nurgush", 610000 Kirov, Russia \\ ${ }^{2}$ Minin Nizhny Novgorod State Pedagogical University, 603950 Nizhny Novgorod, Russia
}

\begin{abstract}
The census of Listera was conducted on routes with a total length of $11.05 \mathrm{~km}$ on 2020 . The width of the recording transect was $10 \mathrm{~m}$. In suitable habitats, plants were located in relatively dense groups, separated from each other by considerable distances. We have revealed 31 subpopulations of Listera with a total of 283 generative shoots and 1949 vegetative ones. The density of Listera in the surveyed habitats was 3.50 ind./ha, density in the subpopulations was from 5 to 13 ind./sq.m, on the average 6.81 ind./sq.m. All the Subpopulations were confined to areas of moss cover dominated by sphagnum mosses, but with the obligatory presence of Polytrichum commune and hypnum mosses. The setting and ripening of Listera fruits in 2020 were high: fruits were developed from $84 \%$ of flowers. The Tulashor site of the Nurgush State Nature Reserve plays an important role for the conservation of Listera cordata in the Kirov region.
\end{abstract}

Listera cordata (L.) R. Br. is listed in the Red Data Books of several regions of Russia, including the Red Book of the Kirov region, category II (a rare species in the recent past, the number of which is rapidly declining). In the Kirov region it is found in five districts (Afanasievsky, Belokholunitsky, Verkhnekamsky, Kirovo-Chepetsky and Podosinovsky). It is protected on the territory of the nature reserve "Bylina" [1]. The Tulashor site of the Nurgush State Nature Reserve is the second protected area of the Kirov region that provides the species with territorial protection. The species was first registered here in July 2017. [2].

The Tulashor site of the Nurgush State Nature Reserve was established in 2010 to protect the southernmost intact patch of European dark-coniferous middle taiga. It is located in the Nagorsky district of the Kirov region on the border with the Komi Republic. The area of the protected area is 17815,5 ha, its protected zone is 17566,1 ha. More than half of the area is occupied by a zonal type of vegetation - middle taiga dark-coniferous forests, mostly 100-200 years old, having recovered on the burnt-out areas of the XIX century. These forests are characterized by mixed-age tree canopy, a well developed complex of gaps, a large number of dead wood of different stages of destruction.

The identification of the places of growth and the counting of specimens of Listera was conducted at the Tulashor site of the Nurgush State Nature Reserve on the routes with a total length of $11.05 \mathrm{~km}$ on 17-26.07.2020. The width of the recording transect was $10 \mathrm{~m}$. The total area under the census, calculated using GIS-methods, was 8.9 ha 
The distribution of Listera in the studied area is very uneven. In suitable habitats, plants are located in relatively dense groups, separated from each other by considerable distances. Hereinafter, we recognize such groups as subpopulations. A total of 31 subpopulations were counted; their total area was $327.55 \mathrm{~m}^{2}$. Identified subpopulations had a total of 283 generative and 1949 vegetative shoots.

Subpopulations of Listera in Tulashor occupied areas from 0.1 to $53 \mathrm{sq} \mathrm{m}$ and contained on average 72 specimens, among which 5-10 vegetative specimens per one generative specimen (Table 1). Distances between subpopulations ranged from $3 \mathrm{~m}$ to $130 \mathrm{~m}$, averaging $24.6 \pm 30.1 \mathrm{~m}$ with a confidence interval of 14.5 to $34.7 \mathrm{~m}$. The density of Listera in subpopulations ranged from 5 to $13 \mathrm{ex} / \mathrm{sq}$. m, averaging $6.81 \mathrm{ex} / \mathrm{sq}$. $\mathrm{m}$ (Table 2).

Table 1. Size indices of subpopulations of Listera in $2020(n=31)$

\begin{tabular}{|c|c|c|c|c|c|}
\hline \multirow{2}{*}{ Index } & \multirow{2}{*}{$\begin{array}{c}\text { Area of the } \\
\text { subpopulatio } \\
\text { n, sq. m. }\end{array}$} & \multicolumn{4}{|c|}{ Number of specimens } \\
\cline { 3 - 6 } & 0.10 & 0.00 & 1.00 & 1.00 & 1.00 \\
\hline Minimum & 53.00 & 46.00 & 369.00 & 415.00 & 36.00 \\
\hline Maximum & 10.57 & 9.13 & 62.87 & 72.00 & 7.34 \\
\hline Mean & 17.06 & 10.78 & 89.15 & 98.23 & 7.45 \\
\hline $\begin{array}{c}\text { Standard } \\
\text { deviation }\end{array}$ & $4.56-16.57$ & $5.33-12.92$ & $31.49-94.25$ & $\begin{array}{c}\text { vegetative } \\
106.42-\end{array}$ & $4.63-10.05$ \\
\hline $\begin{array}{c}\text { Confidence } \\
\text { interval }\end{array}$ & & &
\end{tabular}

Table 2. Density of subpopulations of Listera in $2020(n=31)$

\begin{tabular}{|c|c|c|c|}
\hline \multirow{2}{*}{ Index } & \multicolumn{3}{|c|}{$\begin{array}{c}\text { Density of shoots in subpopulations of } \\
\text { Listera, ind./sq. m. }\end{array}$} \\
\cline { 2 - 4 } & generative & vegetative & total \\
\hline Minimum & 0.00 & 0.73 & 0.89 \\
\hline Maximum & 20.00 & 60.00 & 80.00 \\
\hline Mean & 3.94 & 17.46 & 21.40 \\
\hline $\begin{array}{c}\text { Standard } \\
\text { deviation }\end{array}$ & 4.44 & 15.79 & 19.22 \\
\hline $\begin{array}{c}\text { Confidence } \\
\text { interval }\end{array}$ & $2.38-5.51$ & $11.90-23.02$ & $14.64-28.17$ \\
\hline
\end{tabular}

In all area of the surveyed habitats the average density of subpopulations of Listera was 3.50 ind./ha; density of generative shoots -31.96 ind./ha, vegetative shoots -220.08 ind./ha.

The discovered points of the Listera growing were located in the old-growth taiga. This orchid was not found in young forests of 30-40 years old recovered at the areas of woodcutting. Habitat suitability appears to be determined by soil and moss cover. All subpopulations of Listera were confined to areas of moss cover dominated by sphagnum mosses, but with the obligatory presence of Polytrichum commune and hypnum mosses. In areas where Polytrichum commune and hupnum mosses were dominant or absent, the orchid was not found. It was discovered in not every site that was outwardly suitable for growing. It was not possible to reveal a correlation between the presence and abundance of Listeria and forest inventory characteristics of old-growth taiga fragments. 
In order to make the territory of the Reserve accessible for research and protection, a trail was restored on the site of an old road, abandoned several decades ago. In summer the trail is used only by pedestrians (on average about 20 passages per month), in winter - for snowmobile travel (no more than 10 passages per month). We compared the characteristics of subpopulations (Tables 3,4) and density of Listera near the trail and in the adjoining forest of the buffer zone of the Reserve. In the forest, subpopulations of Listera are reliable larger than near the trail: they occupy larger areas, have more specimens; the ratio of the number of vegetative and generative specimens in subpopulations does not differ (Tables 3 , 4). Its density in the subpopulations near the trail is approximately twice as high as in the forest. The average density of the species in the two sites are very close, near the trail is insignificantly higher. Thus, restoration (clearing) and regular use of the trail to ensure the functioning of the Reserve did not have a negative impact on the state of the Listera population. The differences in the size indices of the species subpopulations near the trail and in the forest appear to be related to a finer mosaic of moss cover areas at the trail sites.

Table 3. Size indices of Listera subpopulations near the trail $(n=12)$

\begin{tabular}{|l|c|c|c|c|c|}
\hline \multirow{2}{*}{ Index } & \multirow{2}{*}{$\begin{array}{c}\text { Area of the } \\
\text { subpopulatio } \\
\text { n, sq. m. }\end{array}$} & \multicolumn{4}{|c|}{ Number of specimens } \\
\cline { 3 - 6 } & 0.10 & 0.00 & 1.00 & 1.00 & 2.13 \\
\hline Minimum & 21.00 & 25.00 & 149.00 & 174.00 & 36.00 \\
\hline Maximum & 3.98 & 6.17 & 44.67 & 50.83 & 8.97 \\
\hline Mean & 6.18 & 7.31 & 55.26 & 60.82 & 9.66 \\
\hline $\begin{array}{l}\text { Standard } \\
\text { deviation }\end{array}$ & $0.49-7.47$ & $2.03-10.3$ & $13.4-75.93$ & $16.42-85.25$ & $3.26-14.68$ \\
\hline $\begin{array}{l}\text { Confidence } \\
\text { interval }\end{array}$ & & & vegetative & total & $\begin{array}{c}\text { vegetative } \\
\text { /generative }\end{array}$ \\
\hline
\end{tabular}

Table 4. Size indices of Listera subpopulations in the adjacent forest area outside the trail $(n=10)$

\begin{tabular}{|l|c|c|c|c|c|}
\hline \multirow{2}{*}{ Index } & \multirow{2}{*}{$\begin{array}{c}\text { Area of the } \\
\text { subpopulatio } \\
\text { n, sq. m. }\end{array}$} & \multicolumn{4}{|c|}{ Number of specimens } \\
\cline { 3 - 6 } & 0.10 & 0.00 & 2.00 & 2.00 & 1.82 \\
\hline Minimum & 53.00 & 46.00 & 369.00 & 415.00 & 21.09 \\
\hline Maximum & 18.82 & 14.40 & 100.60 & 115.00 & 6.82 \\
\hline Mean & 22.63 & 15.39 & 127.67 & 141.09 & 5.70 \\
\hline $\begin{array}{l}\text { Standard } \\
\text { deviation }\end{array}$ & $4.8-32.84$ & $4.86-23.94$ & $\begin{array}{l}21.47- \\
179.73\end{array}$ & $\begin{array}{l}27.56- \\
202.44\end{array}$ & $3.1-10.54$ \\
\hline $\begin{array}{l}\text { Confidence } \\
\text { interval }\end{array}$ & & vegetative & \multicolumn{4}{|c|}{} \\
\hline
\end{tabular}

The number of flowers and fruits per generative specimen of Listera $(n=160)$ was counted. The results of statistical processing of the obtained variation series are presented in Table 5. The setting and ripening of orchid fruits in 2020 were high: fruits were develped from $84 \%$ of flowers.

Thus, 31 subpopulations of Listera were identified as a result of our surveys. All subpopulations are confined to old-growth taiga, to areas of moss cover dominated by sphagnum mosses, with the obligatory presence of Polytrichum commune and hypnum mosses. 
Table 5. Number of flowers and fruits per generative specimen of Listera in $2020(n=160)$

\begin{tabular}{|c|c|c|}
\hline \multirow{2}{*}{ Index } & \multicolumn{2}{|c|}{$\begin{array}{c}\text { Number (per generative } \\
\text { specimen) }\end{array}$} \\
\cline { 2 - 3 } & flowers & fruits \\
\hline Minimum & 2 & 0 \\
\hline Maximum & 10 & 9 \\
\hline Mean & 5.68 & 4.76 \\
\hline Standard deviation & 1.64 & 2.03 \\
\hline Confidence interval & $5.42-5.93$ & $4.45-5.08$ \\
\hline
\end{tabular}

The studied subpopulations of Listera occupied areas from 0.1 to $53 \mathrm{sq} \mathrm{m}$, numbered on average 72 specimens, among which there were 5-10 vegetative specimens per one generative specimen. The density of Listera in subpopulations ranged from 5 to 13 ind./sq. $\mathrm{m}$, with an average of 6.81 ind./sq. $\mathrm{m}$.

When comparing subpopulations growing under the forest canopy and near the trail, we found that the Listera subpopulations in the forest are reliable larger than those near the trail: they occupy larger areas and have a greater number of specimens. The orchid density in the subpopulations near the trail is approximately twice as high as in the forest. The ratio of the number of vegetative and generative specimens in these subpopulations does not differ.

The Tulashor site of the Nurgush State Nature Reserve plays an important role for the conservation of Listera cordata in the Kirov region.

\section{References}

1. Red Data Book of the Kirov Region: animals, plants, fungi (Kirov, Kirov. obl. tip., 2014)

2. S.V. Bakka, N.Yu. Kiseleva, E.M. Tarasova, Proceedings of the Mordovia State Nature Reserve, 25 (2020) 